\title{
Nitrogen compounds and ozone in the stratosphere: comparison of MIPAS satellite data with the chemistry climate model ECHAM5/MESSy1
}

\author{
C. Brühl ${ }^{1}$, B. Steil ${ }^{1}$, G. Stiller ${ }^{2}$, B. Funke ${ }^{3}$, and P. Jöckel ${ }^{1}$ \\ ${ }^{1}$ Max-Planck-Institute for Chemistry, Mainz, Germany \\ ${ }^{2}$ Institute for Meteorology and Climate Research, Forschungszentrum Karlsruhe, Germany \\ ${ }^{3}$ Instituto de Astrofísica de Andalucía, Granada, Spain
}

Received: 1 June 2007 - Published in Atmos. Chem. Phys. Discuss.: 9 July 2007

Revised: 25 October 2007 - Accepted: 30 October 2007 - Published: 12 November 2007

\begin{abstract}
The chemistry climate model ECHAM5/MESSy1 (E5/M1) in a setup extending from the surface to $80 \mathrm{~km}$ with a vertical resolution of about $600 \mathrm{~m}$ near the tropopause with nudged tropospheric meteorology allows a direct comparison with satellite data of chemical species at the same time and location. Here we present results out of a transient 10 years simulation for the period of the Antarctic vortex split in September 2002, where data of MIPAS on the ENVISATsatellite are available. For the first time this satellite instrument opens the opportunity, to evaluate all stratospheric nitrogen containing species simultaneously with a good global coverage, including the source gas $\mathrm{N}_{2} \mathrm{O}$ and ozone which allows an estimate for $\mathrm{NO}_{\mathrm{x}}$-production in the stratosphere. We show correlations between simulated and observed species in the altitude region between 10 and $50 \mathrm{hpa}$ for different latitude belts, together with the Probability Density Functions (PDFs) of model results and observations. This is supplemented by global maps on pressure levels showing the comparison between the satellite and the simulated data sampled at the same time and location. We demonstrate that the model in most cases captures the partitioning in the nitrogen family, the diurnal cycles and the spatial distribution within experimental uncertainty. This includes even variations due to tropospheric clouds. There appears to be, however, a problem to reproduce the observed nighttime partitioning between $\mathrm{N}_{2} \mathrm{O}_{5}$ and $\mathrm{NO}_{2}$ in the middle stratosphere using the recommended set of reaction coefficients and photolysis data.
\end{abstract}

\section{Introduction}

The nitrogen oxides are produced in the stratosphere by oxidation of the mostly biogenic source gas $\mathrm{N}_{2} \mathrm{O}$ involving ex-

Correspondence to: C. Brühl

(chb@mpch-mainz.mpg.de) ited oxygen $\left(\mathrm{O}\left({ }^{1} \mathrm{D}\right)\right)$. They provide the most important catalytic sink for ozone in the middle stratosphere and explain most of the seasonal cycle of total ozone in mid-latitudes (Brühl and Crutzen, 2000; Crutzen and Schmailzl, 1983). They are also responsible for the deactivation of chlorine from the CFCs in the lower stratosphere. In polar winter and spring the heterogeneous conversion of $\mathrm{N}_{2} \mathrm{O}_{5}$ and $\mathrm{ClONO}_{2}$ inside the cold vortices to $\mathrm{HNO}_{3}$ and subsequent denitrification by sedimentation of $\mathrm{HNO}_{3}$ containing polar stratospheric cloud particles set the conditions for the ozone hole, the fast ozone destruction by halogens (Solomon, 1999). Here we present as an efficient way of evaluation point-bypoint comparisons between satellite data and a Chemistry Climate Model (CCM) simulation for all species of the $\mathrm{NO}_{\mathrm{y}}$ family simultaneously, including its source gas and dynamical tracer $\mathrm{N}_{2} \mathrm{O}$ and ozone. The combination of satellite and model data is also used for sensitivity studies on the consequences of new findings in the kinetics of nitrogen oxide reactions and on simplifications in photolysis calculations. Such a study might help to resolve problems present in many CCMs to correctly represent ozone in the lower and middle stratosphere compared to observations (Eyring et al., 2006). On the other hand, comparison between observed trace gas fields from a satellite instrument like MIPAS and a nudged CCM is valuable to check the self-consistency of satellite data.

For a detailed analysis of the dynamics of the Antarctic major warming, the so-called vortex split, we refer to a special issue of Journal of Atmospheric Sciences in March 2005 (e.g. Newman and Nash, 2005).

\section{MIPAS satellite data}

MIPAS (Michelson Interferometer for Passive Atmospheric Sounding) is a Fourier transform spectrometer sounding the

Published by Copernicus Publications on behalf of the European Geosciences Union. 
thermal emission of the earth's atmosphere between 685 and $2410 \mathrm{~cm}^{-1}(14.6-4.15 \mu \mathrm{m})$ in limb geometry (von Clarmann et al., 2003). It is operational on the ENVISAT since summer 2002. We use data from the nominal observation mode $(6-68 \mathrm{~km})$. The field-of-view of the instrument at the tangent points is about $3 \mathrm{~km}$ in the vertical (up to $45 \mathrm{~km}$ ) and $30 \mathrm{~km}$ in the horizontal (longitude). There are 14.3 orbits per day with measurements obtained about every $5^{\circ}$ latitude at day and night at fixed local time (about 10 and $22 \mathrm{~h}$ ) allowing for global coverage in one day. MIPAS was operational from July 2002 to March 2004 with full specification, in particular $0.035 \mathrm{~cm}^{-1}$ spectral resolution. MIPAS data used within this comparison are trace gas distributions retrieved with the IMK/IAA scientific processor based on reprocessed Level-1b data (versions 4.61/62). Spectra containing cloud signal (mainly PSCs in this context) were identified using a method suggested by Spang et al. (2004) and have been excluded from further analysis. The general strategy and formalism of the retrieval is discussed in detail in von Clarmann et al. (2003). Data are available from July 2002 to March 2004 (however, not with complete coverage), except for NO, where only 3 consecutive days during the vortex split period in September 2002 and a few individual days in Winter 2003/2004 were processed up to now.

Typical error ranges in the lower stratosphere of midlatitudes are: $\mathrm{O}_{3} 5 \%$ (Glatthor et al., 2006), $\mathrm{N}_{2} \mathrm{O} 7 \%(+7 \%$ high bias in tropics, Glatthor et al., 2005), $\mathrm{HNO}_{3} 10 \%$ (Wang et al., 2007; Mengistu Tsidu et al., 2005), $\mathrm{NO}_{2} 8 \%$ (night) $18 \%$ (day) (Funke et al., 2005), NO 15\% (day) (Funke et al., 2005), $\mathrm{N}_{2} \mathrm{O}_{5} 30 \%$ (Mengistu Tsidu et al., 2004), $\mathrm{HO}_{2} \mathrm{NO}_{2}$ $19 \%$ (Stiller et al., 2007), $\mathrm{ClONO}_{2} 7-13 \%$ (Höpfner et al., 2007). Improved non-LTE (local thermodynamic equilibrium) retrieval schemes (V8.0) for $\mathrm{NO}$ and $\mathrm{NO}_{2}$ are used. These improvements include i) the use of $\log (\mathrm{VMR})$ instead of VMR (volume mixing ratio) in the retrieval vector, ii) revised non-LTE parameters for $\mathrm{NO}_{2}$, and iii) joint-fitted VMR horizontal gradients at constant longitudes and latitudes. For NO retrievals, a revised set of spectral windows (microwindows) is applied, which allows to measure NO down to altitudes of about $15 \mathrm{~km}$. Compared to Funke et al. (2005) much more valid profiles for the vortex split period are available and the number of NO outlyers is strongly reduced.

\section{The chemical circulation model ECHAM5/MESSy1}

The atmospheric chemistry general circulation model ECHAM5/MESSy1 (E5/M1) is based on the 5th generation European Centre Hamburg GCM, a spectral general circulation model. The configuration applied for this study has a horizontal spectral resolution of T42 (or about $2.8^{\circ}$ for the corresponding quadratic Gaussian grid) and 90 layers from the surface to about $80 \mathrm{~km}$ (1 Pa) (Giorgetta et al., 2006). The vertical resolution in the lower stratosphere is about $600 \mathrm{~m}$. The model is able to calculate the Quasi-Biennial Oscillation internally, i.e., without assimilation of observational data. In the free mode only the sea surface temperatures and mixing ratios or fluxes of chemical species are needed as lower boundary conditions. To allow for a direct and efficient comparison with observations of chemical species in the simulation used for the evaluation, tropospheric temperatures, vorticity and divergence and surface pressure are weakly nudged to ECMWF operational data (700 to $200 \mathrm{hPa}$ ), see Jöckel et al. (2006). The results presented here are part of a transient simulation from 1996 to 2005. As main part of the Modular Earth Submodel System (MESSy, Jöckel et al., 2005), the model has fully interactive and flexible chemistry (Sander et al., 2005) with 104 species and about 250 homogeneous and heterogeneous reactions ( +6 species and 40 reactions in cloud droplets), including interactive photolysis. The scheme covers the most important reactions and species from the troposphere to the mesosphere. The chemical kinetics is mostly based on Sander et al. (2002). As in Stiller et al. (2007), infrared photolysis of $\mathrm{HO}_{2} \mathrm{NO}_{2}$ (short $\left.\mathrm{HNO}_{4}\right)$ is included.

\section{Point-by-point comparisons between model results and satellite data}

For the comparison the model data points closest to the observations in space and time are selected. To avoid deviations due to the strong diurnal cycle of some nitrogen species the study is based on hourly output of the CCM for the selected period (instead of the $5 \mathrm{~h}$ setting in Jöckel et al., 2006).

\subsection{Zonal averages}

For the first time it is possible, to compare simulated global fields of $\mathrm{N}_{2} \mathrm{O}$ and all major compounds of reactive nitrogen $\mathrm{NO}_{\mathrm{y}}=\mathrm{HNO}_{3}+\mathrm{NO}+\mathrm{NO}_{2}+2 \mathrm{~N}_{2} \mathrm{O}_{5}+\mathrm{HNO}_{4}+\mathrm{ClNO}_{3}$ simultaneously with satellite data, using day and night data. First the zonal averages in the stratosphere, based on point-by-point comparisons, for the period from 23 to 25 September 2002 are shown in Fig. 1. Note that due to the peculiar dynamical situation of the split Antarctic vortex only the results north of about $50^{\circ} \mathrm{S}$ should be interpreted as typical. The upper panels in each group show the simulations, the lower panels the relative differences to the MIPAS data. The MIPAS data itself and absolute differences are supplied in the electronic supplement (http://www.atmos-chem-phys.net/7/5585/2007/ acp-7-5585-2007-supplement.pdf). Comparisons for a subset of species for other periods are shown in Jöckel et al. (2006).

From $\mathrm{N}_{2} \mathrm{O}$ (upper left panels) it can be seen that the southern hemispheric subtropical barrier in the model appears to be shifted towards the equator and too strong causing too low $\mathrm{N}_{2} \mathrm{O}$ in the subtropical and mid-latitude middle stratosphere. The transport barriers and their tightness or chemical distinctness have been analysed using the methods described in Sparling (2000). We found for the whole period where 

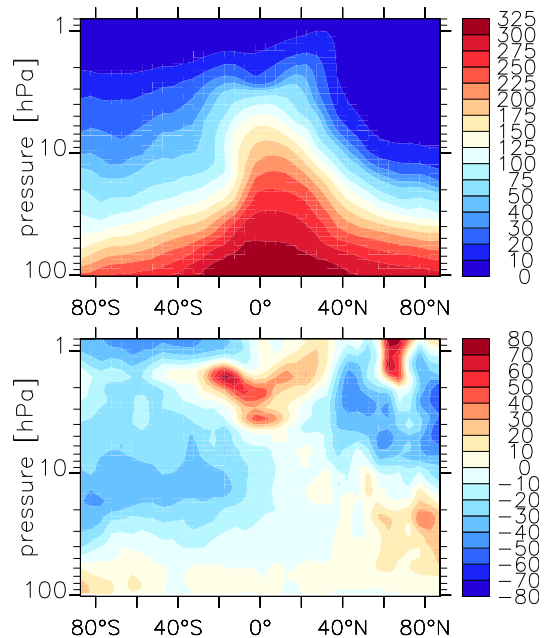

N2O, \%, (E5M1-MIPAS)/MIPAS
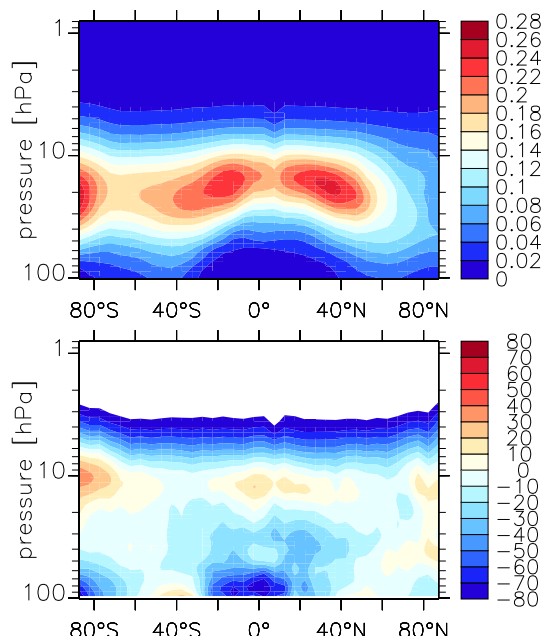

HNO4, \%, (E5M1-MIPAS)/MIPAS
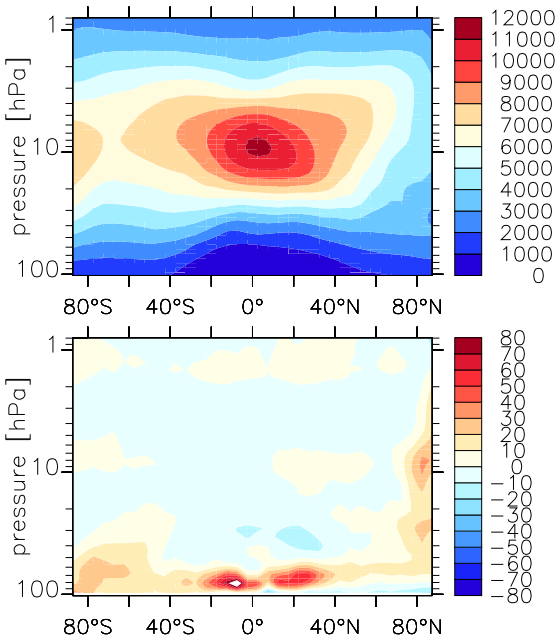

03, \%, (E5M1-MIPAS)/MIPAS
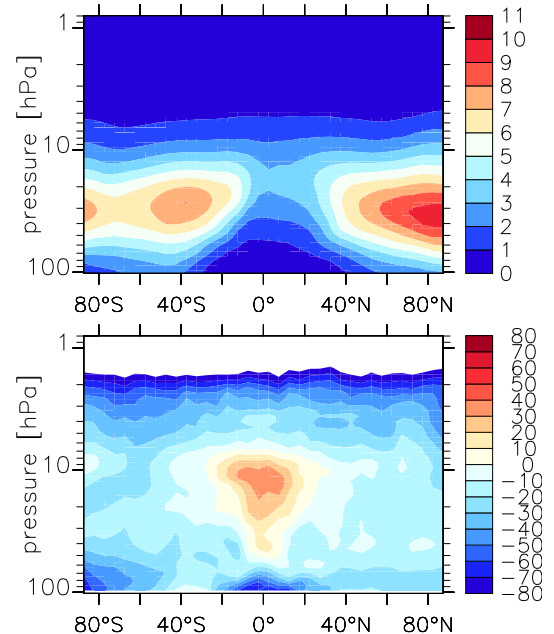

HNO3, \%, (E5M1-MIPAS)/MIPAS

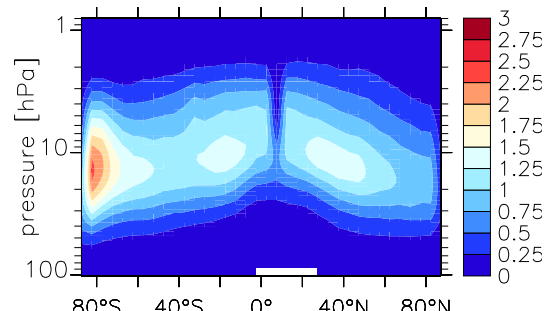

$80^{\circ} \mathrm{S} \quad 40^{\circ} \mathrm{S} \quad 0^{\circ}-40^{\circ} \mathrm{N} \quad 80^{\circ} \mathrm{N}$
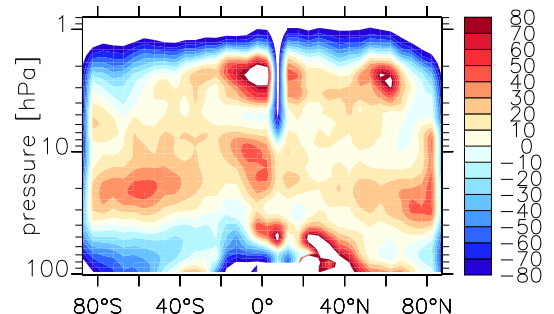

N205, \%, (E5M1-MIPAS)/MIPAS
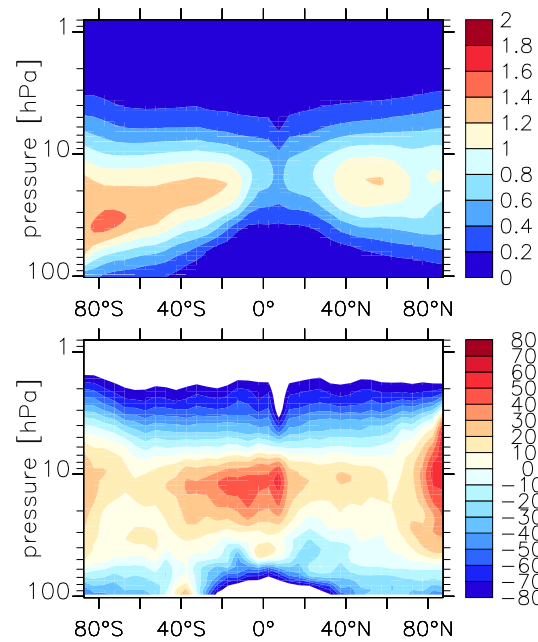

CINO3, \%, (E5M1-MIPAS)/MIPAS
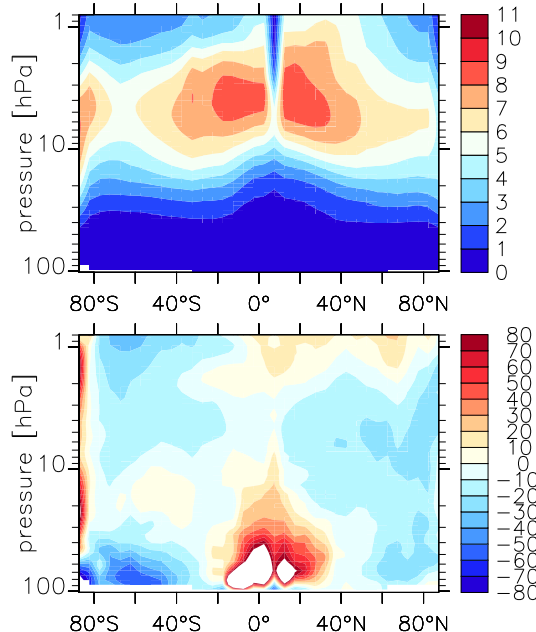

NO2, \%, (E5M1-MIPAS)/MIPAS

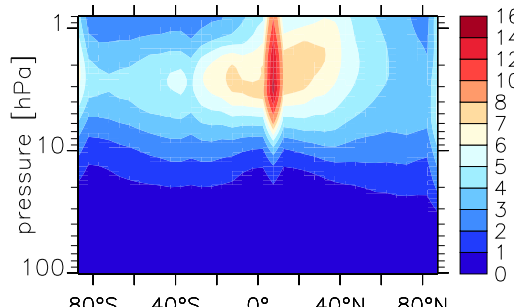

$80^{\circ} \mathrm{S} \quad 40^{\circ} \mathrm{S} \quad 0^{\circ} \quad 40^{\circ} \mathrm{N} \quad 80^{\circ} \mathrm{N}$

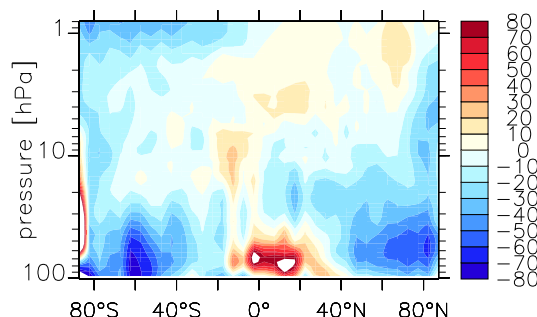

NO, \%, (E5M1-MIPAS)/MIPAS
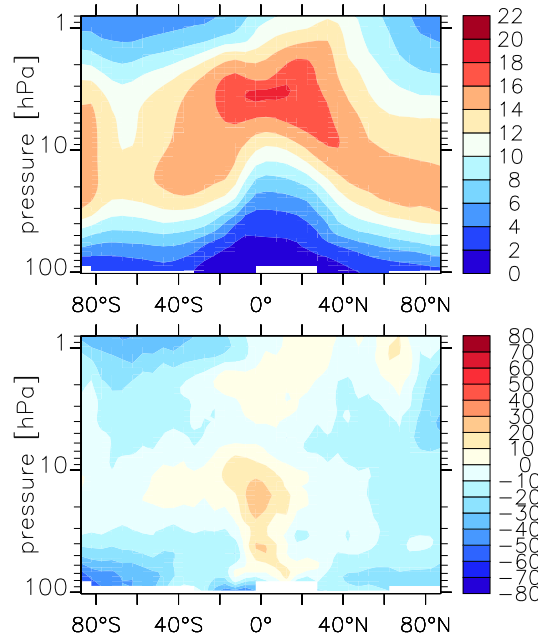

NOY, \%, (E5M1-MIPAS)/MIPAS

Fig. 1. Simulated zonal averages at MIPAS datapoints (ppbv, upper panel) and relative differences to MIPAS (\%, lower panel) for 23-25 September 2002: upper two rows $\mathrm{N}_{2} \mathrm{O}, \mathrm{HNO}_{3}, \mathrm{NO}_{2}$, middle two rows $\mathrm{HNO}_{4}, \mathrm{~N}_{2} \mathrm{O}_{5}, \mathrm{NO}$, lower two rows $\mathrm{O}_{3}, \mathrm{ClNO}_{3}$ and $\mathrm{NO}_{\mathrm{y}}$. Note that at $8^{\circ} \mathrm{N}$ MIPAS has only daytime data. 

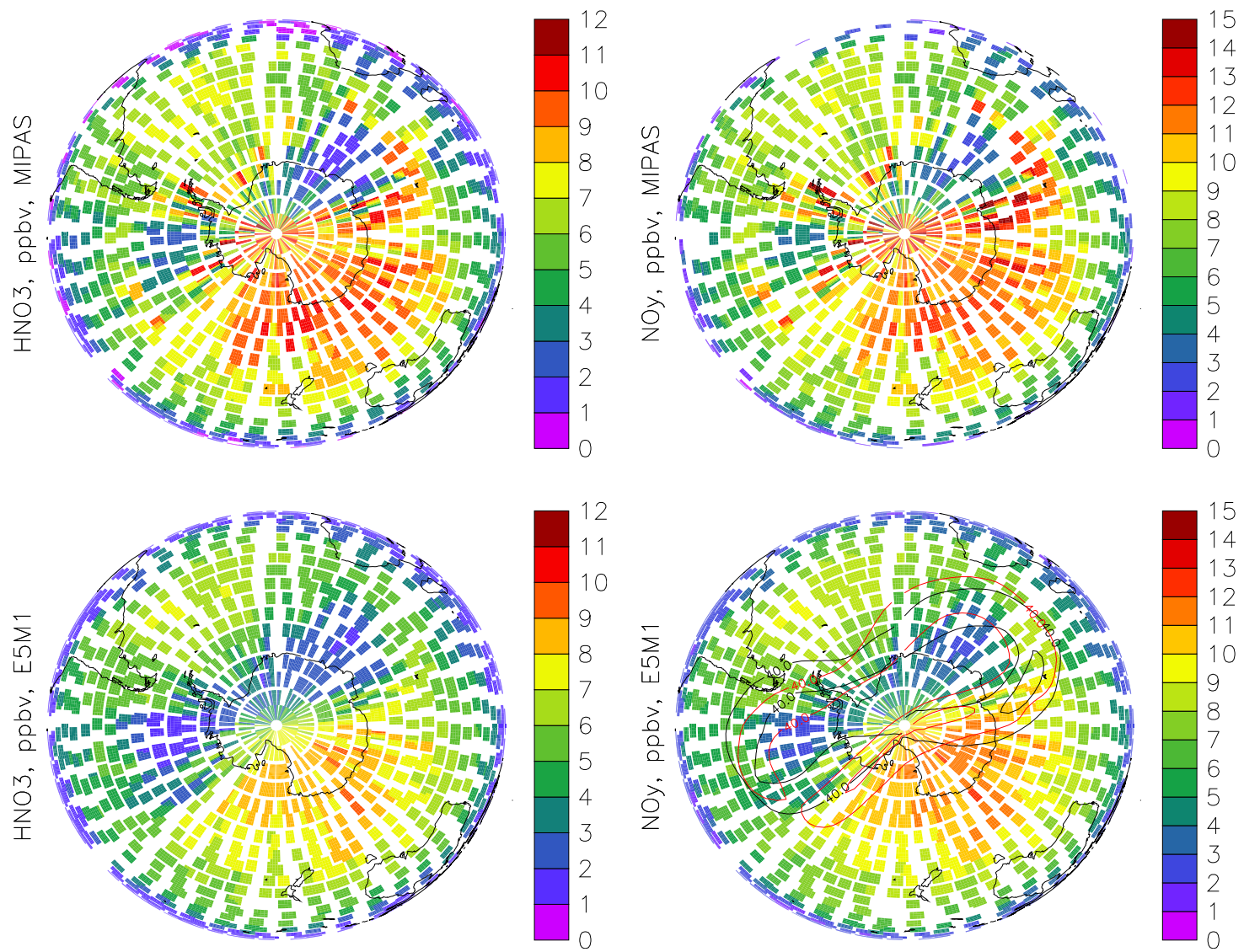

Fig. 2. $\mathrm{HNO}_{3}$ and $\mathrm{NO}_{\mathrm{y}}$ at $50 \mathrm{hPa}$, showing the split vortex over Antarctica. Upper panels: MIPAS observations, lower panels: simulations with E5/M1 for 23-25 September 2002. The contours show the position of the wind maximum (m/s) on 23 September (red) and 25 September (black) as indicator of the vortex edge.

MIPAS $\mathrm{N}_{2} \mathrm{O}$ data were available that the model tends to have such a behaviour with maximum differences in tightness in September 2003, where the phase of the QBO is opposite to September 2002. A shifted and too tight barrier is consistent with too high $\mathrm{NO}_{\mathrm{y}}$ (lower right panels) in the southern subtropics, indicating processed air coming from above and separated from the tropics. Here the differences can reach $20 \%$. The anti-correlation to $\mathrm{N}_{2} \mathrm{O}$ in the middle stratosphere is also visible in the individual nitrogen compounds shown in the other panels of Fig. 1. The largest differences in $\mathrm{N}_{2} \mathrm{O}$ and $\mathrm{NO}_{\mathrm{y}}$ are in the lowermost stratosphere near the southpole indicating a too weak downward motion in the model and maybe too much removal of $\mathrm{HNO}_{3}$ by sedimentation of PSC particles. Since here the zonal average covers airmasses from inside and outside the vortices, including regions with strong horizontal gradients, differences can be also due to the different horizontal resolution of the observations and the model (see also next section). On the other hand, the uncertainties of the satellite data are also largest there. In the northern hemispheric lower stratosphere the model agrees with the observations within their uncertainty range.
The data sets for day and night in the simulation and in the observations are consistent, as can be seen from the fact that the spikes in $\mathrm{NO}, \mathrm{NO}_{2}$ and $\mathrm{N}_{2} \mathrm{O}_{5}$ (and weaker in $\mathrm{HNO}_{4}$ and $\mathrm{ClNO}_{3}$ ) appearing in a latitude belt around $8^{\circ} \mathrm{N}$, where only daytime observations are available, vanish in total $\mathrm{NO}_{\mathrm{y}}$. The large differences in the partitioning between $\mathrm{N}_{2} \mathrm{O}_{5}$ and $\mathrm{NO}_{\mathrm{x}}\left(=\mathrm{NO}+\mathrm{NO}_{2}\right)$ near the south-pole are due to latitude mismatches between model data and observations which are critical at the terminator and due to the impact of large horizontal gradients on the satellite data retrieval. The day night differences will be discussed in more detail in the next sections. The vertical difference patterns in ozone and $\mathrm{HNO}_{4}$ are mostly related to the lower vertical resolution of the satellite data compared to the model. As shown in Jöckel et al. (2006) and Stiller et al. (2007) these differences would be reduced if the model data would be convolved with averaging kernels of the satellite data. 
4.2 The southern vortex split, spatial distribution of nitrogen species and ozone

The lower stratospheric dynamics and the distribution of ozone is to a large extent controlled by planetary waves propagating from the troposphere. Nudging of the tropospheric meteorology enables the model to reproduce the major stratospheric warming and the remarkable split of the Antarctic vortex in September 2002 consistent with the findings of Newman and Nash (2005). Here we focus on the altitude levels $50 \mathrm{hPa}$ (interesting for polar heterogeneous chemistry) and $10 \mathrm{hPa}$ (interesting for nitrogen summer chemistry and dynamics).

\subsubsection{Lower stratosphere}

The two remnants of the split vortex can be clearly seen in the quasi-synoptic view of the observations and the simulations of $\mathrm{HNO}_{3}$ and the total reactive nitrogen $\mathrm{NO}_{\mathrm{y}}$ at $50 \mathrm{hPa}$ in Fig. 2. In the lower right panel the vortex edges with a wind maximum are indicated by the simulated wind contours for the first and third day of the shown period. The features look rather similar except that in the observations the peaks of $\mathrm{HNO}_{3}$ and $\mathrm{NO}_{\mathrm{y}}$ near the edges of the vortices are more distinct than in the simulation.

Figure 3 shows the global view including also $\mathrm{N}_{2} \mathrm{O}$, $\mathrm{O}_{3}$ and all the individual reactive nitrogen species, where the simultaneous observations are available for the first time. Here the upper panels of each group show the model results and the lower panels the absolute deviations from the satellite data. The satellite data itself and the relative differences are provided in the electronic supplement (http://www.atmos-chem-phys.net/7/5585/2007/ acp-7-5585-2007-supplement.pdf). Since the footprints of the nighttime and daytime parts of the orbits (ascending and descending nodes) intersect on the maps, for $\mathrm{NO}, \mathrm{NO}_{2}$ and $\mathrm{N}_{2} \mathrm{O}_{5}$, the species with the largest diurnal variation, day and night are shown separately to avoid noisy maps. As criterion for day a solar zenith angle smaller $93^{\circ}$ in the satellite data is selected in consistency with the photolysis calculation. Nighttime (late evening) $\mathrm{NO}_{2}$ and daytime $\mathrm{NO}$ have similar spatial patterns with maxima in the subtropics and minima in the two parts of the Antarctic vortex. For daytime $\mathrm{NO}$ in low latitudes the differences are noisy due to the effects of reflected radiation from tropospheric clouds on $\mathrm{NO}_{2}$ photolysis (which cannot be expected to be coherent).

The largest differences occur near the vortex edges due to resolution differences and slight offsets of the wave patterns. In general the model reproduces the observed distribution of ozone, $\mathrm{N}_{2} \mathrm{O}$, total nitrogen and the partitioning (see also http://www.atmos-chem-phys.net/7/5585/2007/ acp-7-5585-2007-supplement.pdf) of the nitrogen species, including the diurnal cycle and the denitrification in the Antarctic vortices. The ozone depletion in the vortices by halogens is somewhat underestimated, mostly due to an un- derestimate of downward transport of chlorine into the lower stratosphere in Antarctic winter (Jöckel et al., 2006). The underestimate of downward transport is also indicated by too high $\mathrm{N}_{2} \mathrm{O}$ inside the vortices (see also Fig. 1). On the other hand $\mathrm{N}_{2} \mathrm{O}$ in southern mid-latitudes and between the vortex lobes is too low, which may indicate too much mixing at the vortex edge. For $\mathrm{HNO}_{3}, \mathrm{NO}_{2}$ and $\mathrm{NO}_{\mathrm{y}}$ the eastern and western vortex lobes in the observations are more different concerning denitrification than in the model. $\mathrm{HNO}_{4}$ is too high in southern mid-latitudes and between the vortices. $\mathrm{NO}, \mathrm{NO}_{2}$ and $\mathrm{N}_{2} \mathrm{O}_{5}$ show the largest differences near the south pole pointing to effects of the different horizontal resolution (maximum mismatch about $2^{\circ}$ latitude) and not well defined longitude of the observations, or possibly, artifacts in the retrieval of the satellite data due to the large horizontal gradients near the terminator, where the satellite moves from day to night and the backward view of the sunlit limb is impacted by $\mathrm{N}_{2} \mathrm{O}_{5}$ rich air in the dark part of the optical path.

For chlorine nitrate the relatively large differences in the vortices are related to the coarser vertical resolution of the MIPAS data compared to the model and to the fact that the underestimated ozone depletion favours the formation of chlorine nitrate instead of $\mathrm{HCl}$ when there are no more polar stratospheric clouds, i.e. in the chlorine deactivation phase. In both, observations and simulations there is still a $\mathrm{ClNO}_{3}-$ collar at the edges of the vortex lobes (Höpfner et al., 2004). Here $\mathrm{ClNO}_{3}$ can contribute up to about $35 \%$ to $\mathrm{NO}_{\mathrm{y}}$.

\subsubsection{Middle stratosphere}

In the results for $10 \mathrm{hPa}$ shown in Fig. 4 the differences are largest near the southern subtropical barrier which appears to be shifted towards the equator in the model in this altitude region as can be seen from too low $\mathrm{N}_{2} \mathrm{O}$ and too high $\mathrm{NO}_{\mathrm{y}}$ (including $\mathrm{HNO}_{3}$ ) at about $15^{\circ} \mathrm{S}$ (compare Fig. 1). In the model $\mathrm{N}_{2} \mathrm{O}$ in the southern mid-latitudes is low biased and $\mathrm{NO}_{\mathrm{y}}$ high biased because of a too tight subtropical barrier.

Despite the differences due to the dynamics the partitioning of $\mathrm{NO}_{\mathrm{y}}$ is well represented in the simulation as shown for the major species in Fig. 5 and for the full set for daytime and nighttime conditions in the electronic supplement (http://www.atmos-chem-phys.net/7/5585/2007/ acp-7-5585-2007-supplement.pdf). In both, the observations and the simulations, the anticorrelation between $\mathrm{NO}$ and $\mathrm{NO}_{2}$ due to cloud effects on $\mathrm{NO}_{2}$ photolysis is visible. At the south-pole the partitioning between $\mathrm{N}_{2} \mathrm{O}_{5}$ and $\mathrm{NO}+\mathrm{NO}_{2}$ is shifted towards $\mathrm{NO}+\mathrm{NO}_{2}$ in the model because of permanent $\mathrm{N}_{2} \mathrm{O}_{5}$ photolysis, while the observations might be artificially effected by high nighttime $\mathrm{N}_{2} \mathrm{O}_{5}$ (see above). There are also large differences near the western vortex lobe near the south pole in $\mathrm{NO}_{\mathrm{y}}$ probably due to differences in the wave patterns. The simulated reservoir species $\mathrm{ClONO}_{2}$ is high in the Arctic, while $\mathrm{HNO}_{3}$ is low there as already seen in Fig. 1. In the Antarctic the observed split vortex is well 

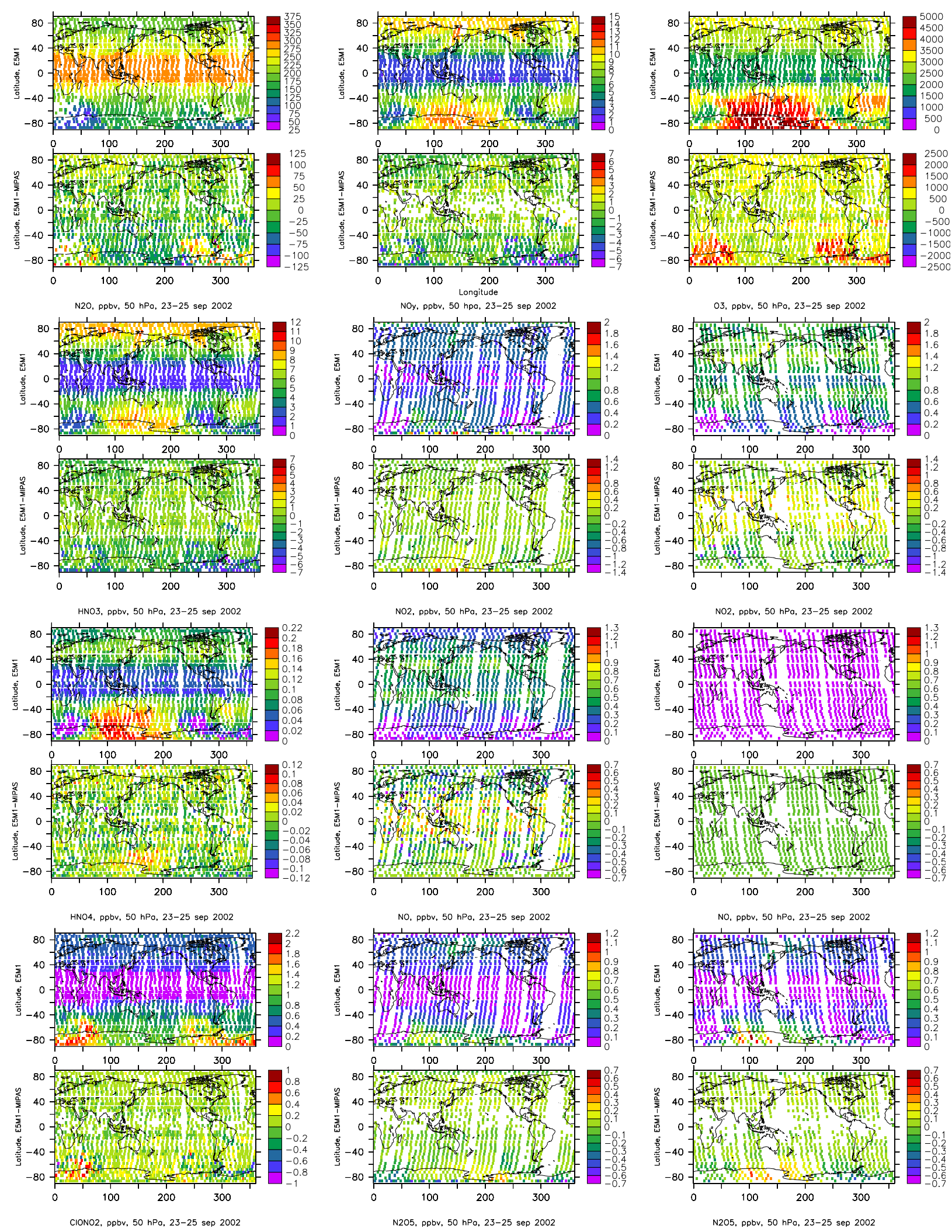

Fig. 3. $\mathrm{N}_{2} \mathrm{O}, \mathrm{NO}_{\mathrm{y}}, \mathrm{O}_{3}$ (first 2 rows), $\mathrm{HNO}_{3}, \mathrm{NO}_{2}$ day and night (second 2 rows), $\mathrm{HNO}_{4}, \mathrm{NO}$ day and night (third 2 rows), $\mathrm{ClONO}_{2}\left(\mathrm{ClNO}_{3}\right.$ ), $\mathrm{N}_{2} \mathrm{O}_{5}$ day and night (fourth 2 rows) at $50 \mathrm{hPa}$ for 23-25 September 2002 as simulated by ECHAM5/MESSy1 (upper panels) and absolute deviations of the model to MIPAS observations (point-by-point in space and time, lower panels of each group). 

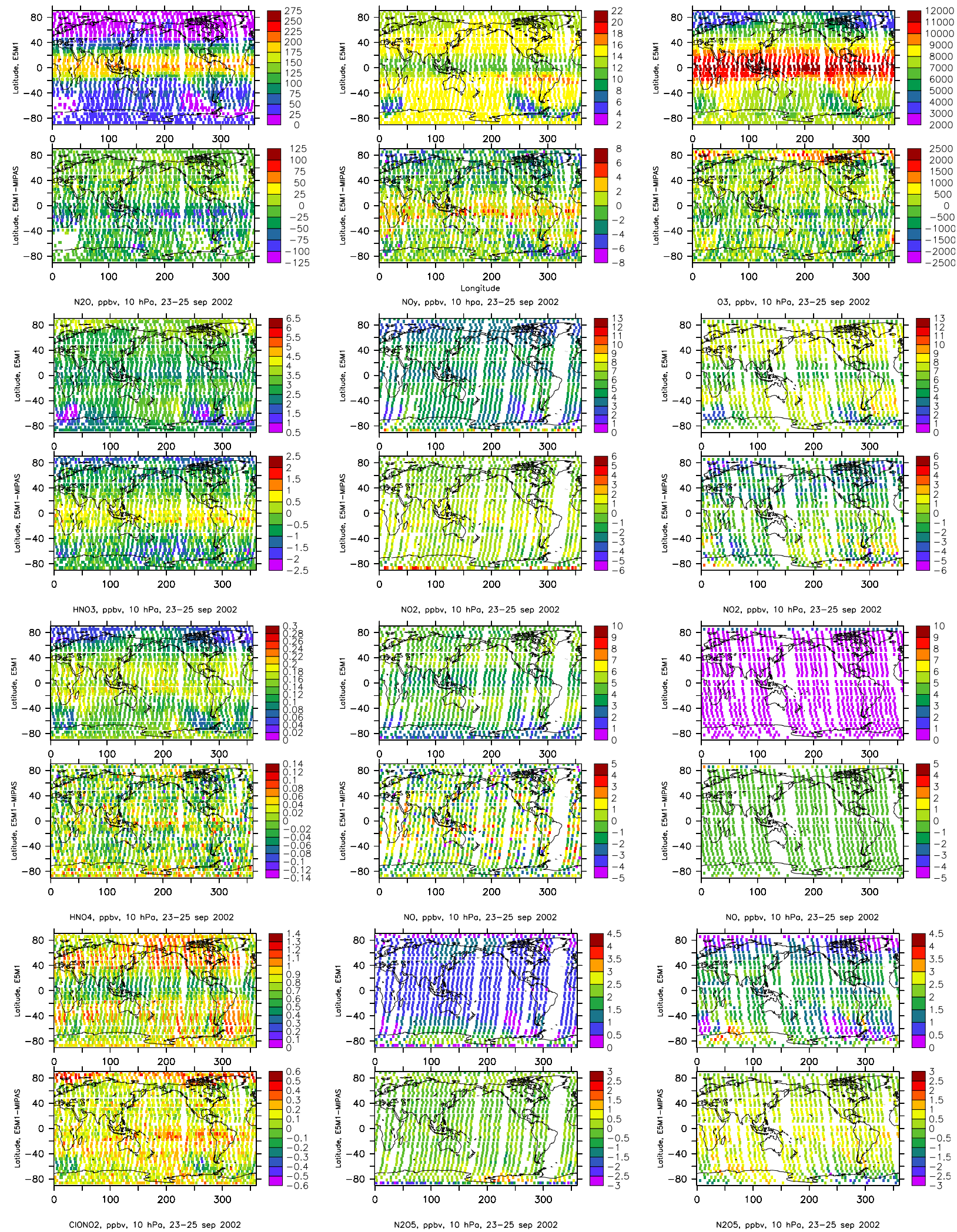

Fig. 4. As Fig. 3 but for $10 \mathrm{hPa}$. 

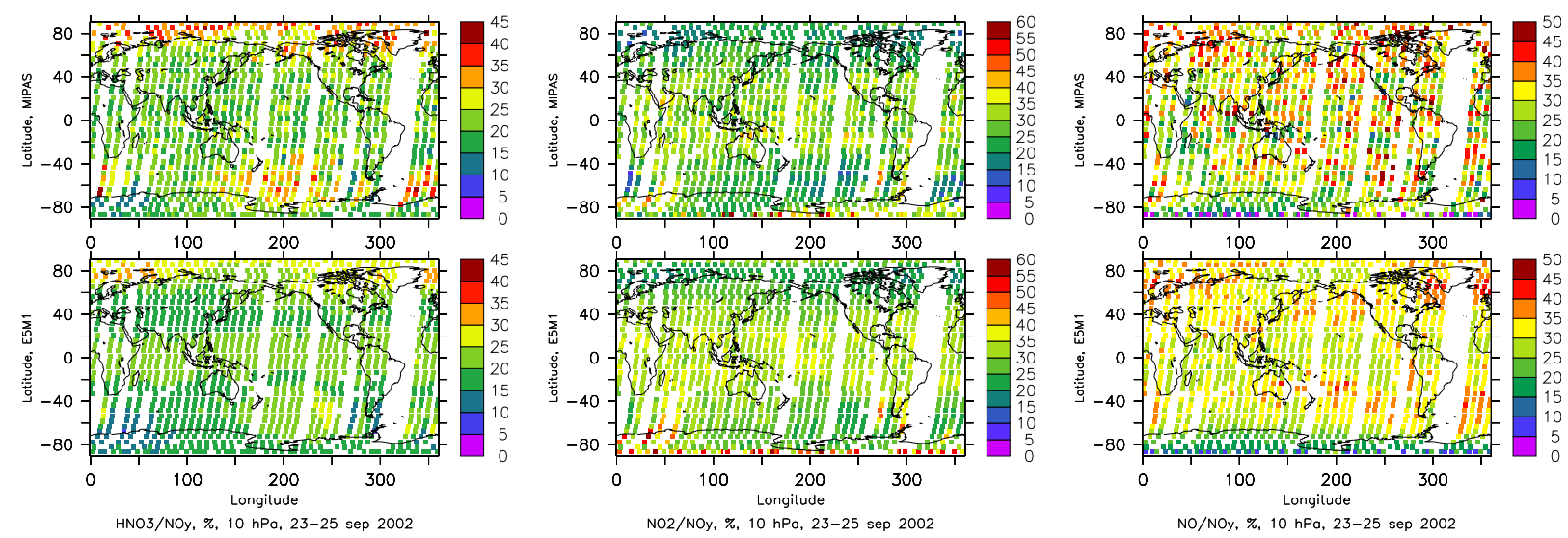

Fig. 5. $\mathrm{NO}_{\mathrm{y}}$ partitioning at $10 \mathrm{hPa}$ in the observations (top) and the simulations (bottom) at daytime. $\mathrm{HNO}_{3}$ (left), $\mathrm{NO}_{2}$ (middle), $\mathrm{NO}$ (right).
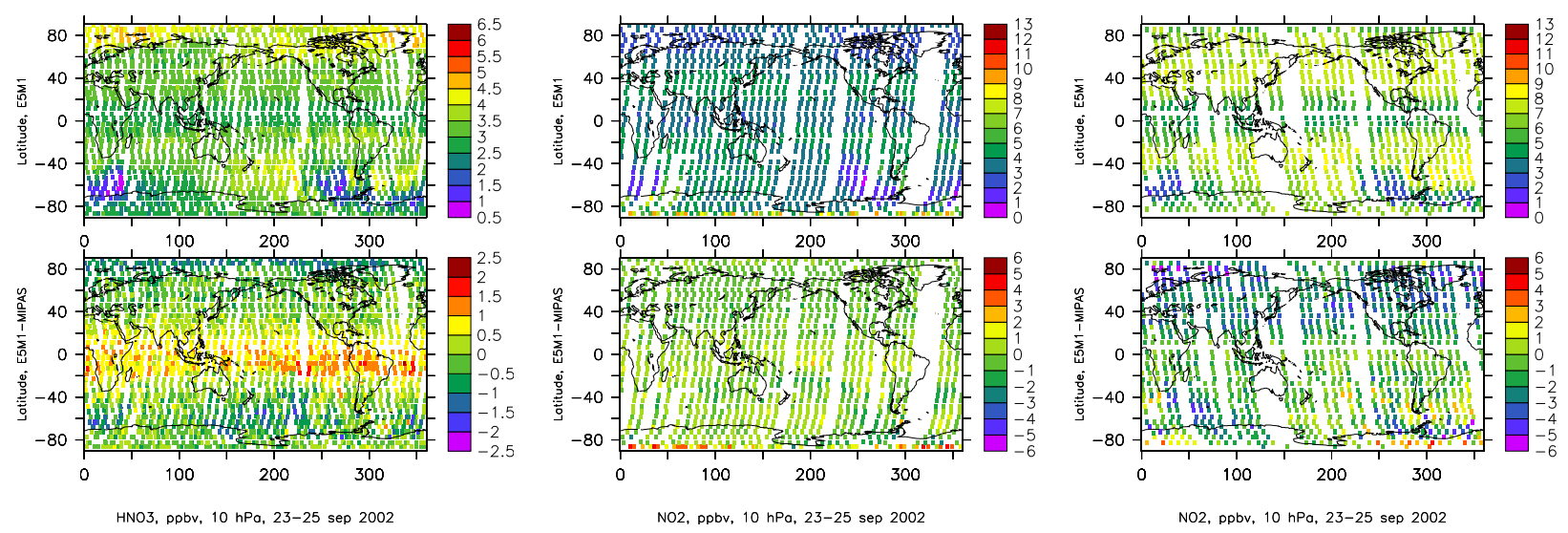

Fig. 6. $\mathrm{HNO}_{3}$ and day and night $\mathrm{NO}_{2}$ at $10 \mathrm{hPa}$ in the sensitivity simulation including the reaction pathway of Butkovskaya et al. (2005). Upper panels: simulation, lower panels: difference to MIPAS.

represented in the simulations, except for a maybe slightly overestimated denitrification from overestimated PSCs there (see $\mathrm{NO}_{\mathrm{y}}, \mathrm{HNO}_{3}, \mathrm{NO}_{2}$ and $\mathrm{ClNO}_{3}$ in Fig. 4). The reason for the low model $\mathrm{HNO}_{3}$ in the vortices can also be the neglect of a new reaction leading from $\mathrm{NO}_{\mathrm{x}}$ to $\mathrm{HNO}_{3}$ : $\mathrm{NO}+\mathrm{HO}_{2} \rightarrow \mathrm{HNO}_{3}$ (Butkovskaya et al., 2005). Inclusion of this reaction in a sensitivity simulation leads to better agreement for $\mathrm{HNO}_{3}$ (see Fig. 6 compared to Fig. 4) because this provides a significant source for $\mathrm{HNO}_{3}$ (and a sink for $\mathrm{NO}_{\mathrm{x}}$ ) in the middle and upper stratosphere where the vortex air originates from. $\mathrm{HNO}_{3}$ at the vortex lobes increases with the additional reaction pathway by about $0.5 \mathrm{ppbv}$. As can be seen from Fig. 6, also $\mathrm{NO}_{2}$ in the midlatitudes gets closer to the observations.
4.3 Comparison based on correlations and probability density functions

Instead of comparing patterns as in the previous section, here we analyse point-by-point correlations and probability density functions (PDFs) for mixing ratios in latitude bins. For the correlations day and night are analysed separately. As examples we show in Fig. 7 the lower stratosphere at high southern latitudes and in Fig. 8 the middle stratosphere in northern mid-latitudes, corresponding to Figs. 3 and 4, respectively. The first example is selected to illustrate the effects of dynamics and heterogeneous chemistry, the second for typical late summer gas-phase chemistry.

In high southern latitudes at $50 \mathrm{hPa}$ (Fig. 7) the PDFs for the observations and the simulation are rather similar, except for the low bias of $\mathrm{N}_{2} \mathrm{O}$ outside the vortex lobes in the model (as discussed before) and more high $\mathrm{HNO}_{3}$ and $\mathrm{NO}_{\mathrm{y}}$ values in the observations. The vortex peaks in the PDFs for $\mathrm{N}_{2} \mathrm{O}$ and $\mathrm{NO}_{\mathrm{y}}$ in the model data and the observations (low values) 



Fig. 7. Point-by-point correlations of MIPAS data to ECHAM5/MESSy 1 results and probability density functions (PDF) for 50 to $90^{\circ} \mathrm{S}$ at $50 \mathrm{hPa}, 23-25$ September 2002. Scatterplots: day red, night black; PDFs: MIPAS red, model blue. Upper rows: $\mathrm{N}_{2} \mathrm{O}$, total nitrogen $\mathrm{NO}_{\mathrm{y}}$, $\mathrm{HNO}_{3}$, and $\mathrm{HNO}_{4}$; lower rows: $\mathrm{N}_{2} \mathrm{O}_{5}, \mathrm{NO}, \mathrm{NO}_{2}$, and $\mathrm{ClONO}_{2} . R$ is the correlation coefficient, $N$ the number of data points in the latitude bin (separate for day and night). For the PDFs the bins for the observations are shifted by $10 \%$ of the binsize for better visibility.

are close together, while the peaks for non-vortex air (high values) are different. For NO the zero nighttime values have a probability of about $50 \%$ in the model data and the observations which is consistent with equinox conditions. For $\mathrm{NO}_{2}, \mathrm{~N}_{2} \mathrm{O}_{5}$ and $\mathrm{HNO}_{4}$ very low values are more likely in the simulations than in the observations. Comparison with Fig. 3 reveals that these low values occur in vortex air pointing to slight differences in heterogeneous chemistry.
In the middle stratosphere of the northern mid-latitudes (10 hPa, Fig. 8) the variability of $\mathrm{HNO}_{3}, \mathrm{NO}$ and $\mathrm{NO}_{\mathrm{y}}$, which is dominated by $\mathrm{NO}$ in this altitude, is larger in the observations than in the simulation. As a consequence, for $\mathrm{NO}_{\mathrm{y}}$ the width of the PDF of the observations is much larger than the one for the model, however, the PDFs peak around about the same value with $16 \mathrm{ppbv}$ in the observations and $15.4 \mathrm{ppbv}$ in the simulation. This behaviour implies rela- 

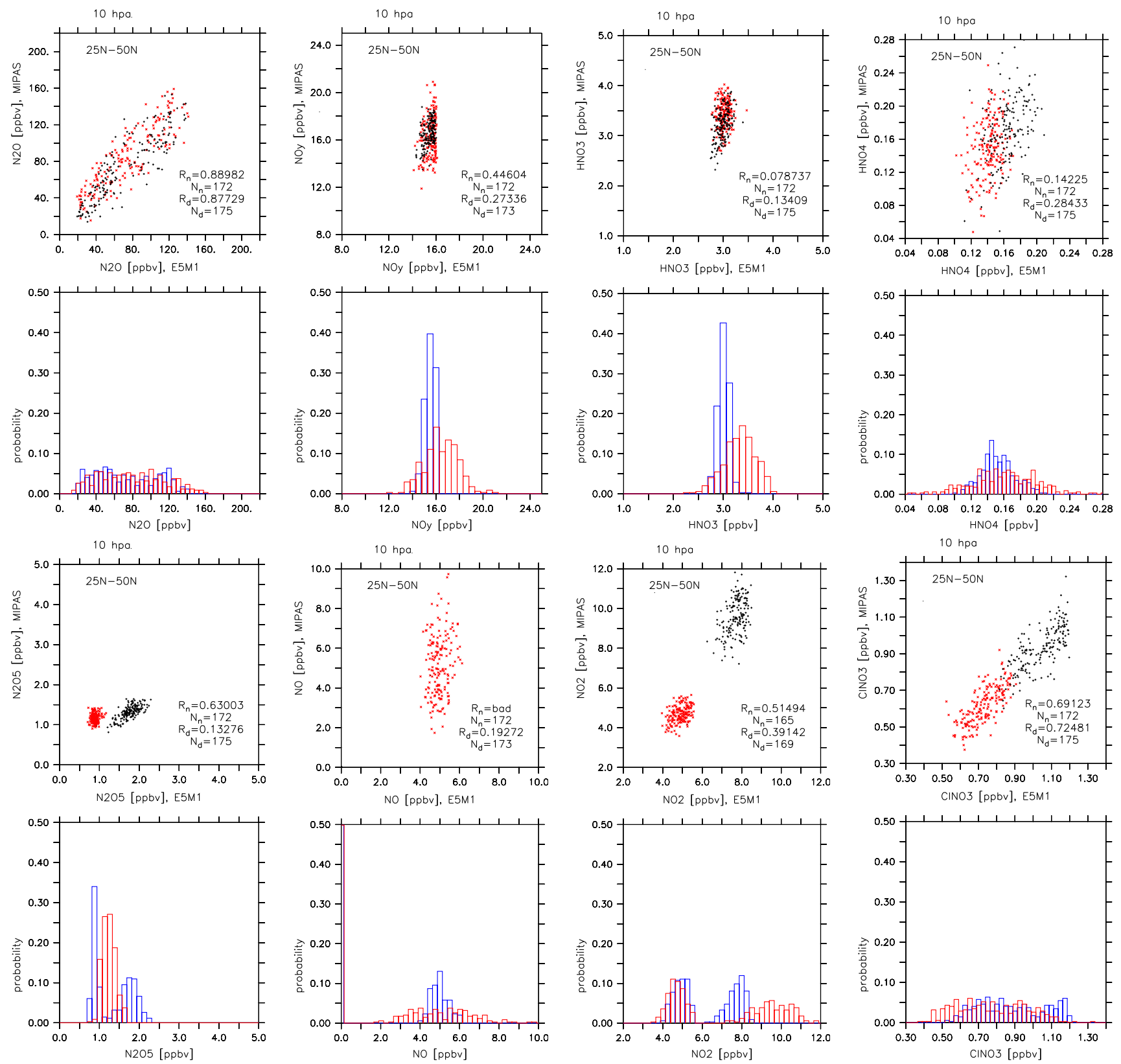

Fig. 8. As Fig. 7 but for 25 to $50^{\circ} \mathrm{N}$ at $10 \mathrm{hPa}, 23-25$ September 2002. Note the zero values for nighttime NO. MIPAS red, model blue.

tively low correlations. In contrast to the high latitude lower stratosphere shown in Fig. 7, $\mathrm{HNO}_{4}$ and $\mathrm{ClNO}_{3}$ have a clear diurnal variation. In $\mathrm{NO}_{2}$ and $\mathrm{NO}$ in observations and simulations the clusters related to the diurnal cycle are visible, however, the nighttime peak for $\mathrm{NO}_{2}$ in the model is low biased. For $\mathrm{N}_{2} \mathrm{O}_{5}$ the model tends to overestimate the diurnal cycle in the middle stratosphere which was already indicated at $50 \mathrm{hPa}$. The high bias at nighttime ( $22 \mathrm{~h}$ local time) is consistent with the diurnal behaviour of $\mathrm{NO}_{2}$. It can neither be explained by more $\mathrm{NO}_{3}$ formation due to about $3 \%$ too high ozone in this region (Fig. 1), nor by a temperature bias. The diurnal sampling of the simulation data should give only a small contribution to the differences, since for the selected equinox conditions the observations are about 4 hours apart from sunset or sunrise (except for the poles). Inclusion of $\mathrm{NO}+\mathrm{HO}_{2} \rightarrow \mathrm{HNO}_{3}$ and the channel to $\mathrm{NO}_{3}+\mathrm{NO}+\mathrm{O}$ in $\mathrm{N}_{2} \mathrm{O}_{5}$ photolysis (which was neglected in the setup described in Jöckel et al., 2006) reduces the discrepancies slightly as shown in Fig. 9. We have performed several sensitivity studies using additional pathways in the photolysis calculations or changes in reaction coefficients given in the most recent recommendation (Sander et al., 2006), without achieving a 

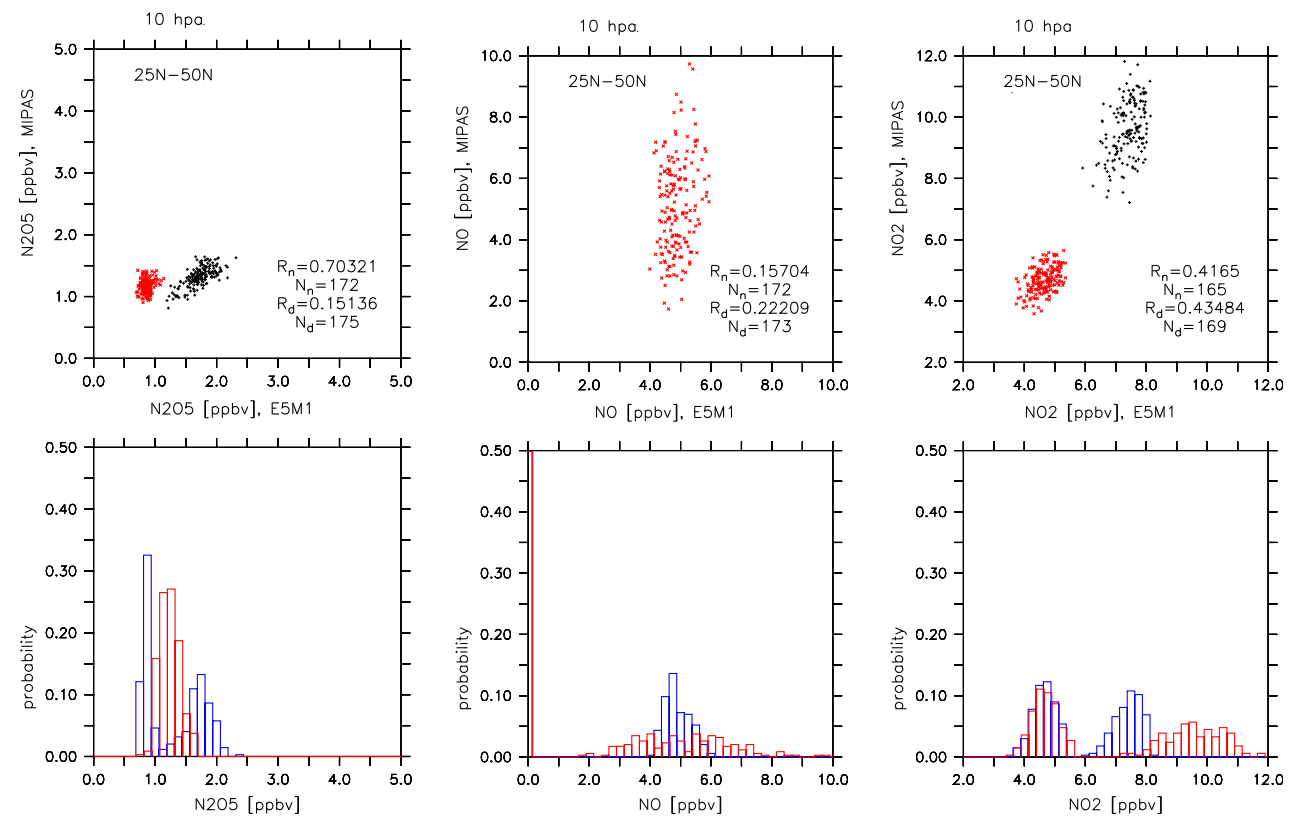

Fig. 9. Sensitivity simulation with the reaction of Butkovskaya et al. (2005) and a more detailed photolysis of $\mathrm{N}_{2} \mathrm{O}_{5}$ for $\mathrm{N}_{2} \mathrm{O}_{5}, \mathrm{NO}$ and $\mathrm{NO}_{2}$ at $10 \mathrm{hPa}$, colors and symbols as in Fig. 7.

significantly better agreement with the observations for the late evening values of $\mathrm{NO}_{2}$ and $\mathrm{N}_{2} \mathrm{O}_{5}$. The discrepancy is also not sensitive to the twilight parameterization in the calculation of photolysis rates. It is still unresolved, if the representation of the homogeneous and heterogeneous chemistry in the model is incomplete, or a problem with absorption cross sections or quantum yields of $\mathrm{N}_{2} \mathrm{O}_{5}$ photolysis is the reason, or a problem with the satellite observations causes the discrepancies in the diurnal cycle in northern midlatitude autumn.

\section{Production of reactive nitrogen from $\mathrm{N}_{2} \mathrm{O}$}

MIPAS $\mathrm{N}_{2} \mathrm{O}, \mathrm{O}_{3}$ and temperature together with the $\mathrm{O}\left({ }^{1} \mathrm{D}\right) / \mathrm{O}_{3}$ ratio from $\mathrm{E} 5 / \mathrm{M} 1$ are used to derive the chemical production of $\mathrm{NO}_{\mathrm{y}}$. Fig. 10 shows the production at about $10 \mathrm{~h}$ local time at the satellite points at 2 altitudes. The values are about 3 times the diurnal average which is consistent with the diurnal cycle of $\mathrm{O}\left({ }^{1} \mathrm{D}\right)$. The individual data-points show a variability due to the dynamics in $\mathrm{N}_{2} \mathrm{O}$ and due to cloud effects on the photolysis of $\mathrm{O}_{3}$ leading to $\mathrm{O}\left({ }^{1} \mathrm{D}\right)$. Using the model data only at the satellite data points leads to somewhat less $\mathrm{NO}_{\mathrm{y}}$ production in the middle stratosphere reflecting the bias of MIPAS $\mathrm{N}_{2} \mathrm{O}$ and differences in the dynamics of the southern hemisphere already identified in Fig. 4. This is consistent with the slightly lower $\mathrm{NO}_{\mathrm{y}}$ shown in Fig. 8. At $50 \mathrm{hPa}$ the effects of the differences in $\mathrm{O}_{3}$ and $\mathrm{N}_{2} \mathrm{O}$ shown in Fig. 3 almost compensate with respect to production of reactive nitrogen. The main patterns are similar to the average production calculated purely from the model in the lower- most panels, supporting the consistency between $\mathrm{N}_{2} \mathrm{O}$ and $\mathrm{NO}_{\mathrm{y}}$ already seen from the previous figures. Clearly visible are again the two lobes of the Antarctic vortex where $\mathrm{NO}_{y^{-}}$ production is low due to low $\mathrm{N}_{2} \mathrm{O}$ and $\mathrm{O}_{3}$.

\section{Conclusions}

ECHAM5/MESSy1 with nudged tropospheric meteorology captures most of the features of nitrogen species observed by MIPAS on ENVISAT in the lower stratosphere, including the 2002 Antarctic vortex split and the diurnal variation of NO and $\mathrm{NO}_{2}$. MIPAS allows a complete evaluation of the $\mathrm{NO}_{\mathrm{y}}{ }^{-}$ family and the nitrogen budget. The partitioning of nitrogen species in the model especially in mid-latitudes and tropics agrees well with observations (if NIR-photolysis of $\mathrm{HO}_{2} \mathrm{NO}_{2}$ is included). There are, however, differences in the diurnal behaviour of $\mathrm{N}_{2} \mathrm{O}_{5}$ and $\mathrm{NO}_{2}$ in the middle stratosphere. As shown by sensitivity studies they cannot be explained by the model dynamics, resolution differences or given uncertainties in the chemistry used in the calculations. There might be the need for more laboratory work.

The model underestimates the downward transport in the lowermost parts of the vortices with the consequence of underestimated ozone depletion by reactive halogens, and a shift to chlorine-nitrate in the chlorine partitioning. Another model feature is the too tight southern subtropical barrier causing too low $\mathrm{N}_{2} \mathrm{O}$ and too high $\mathrm{NO}_{\mathrm{y}}$ in the middle stratosphere of southern mid-latitudes. Here appears to be a need to improve the model dynamics, particularly the forcing by gravity waves. 

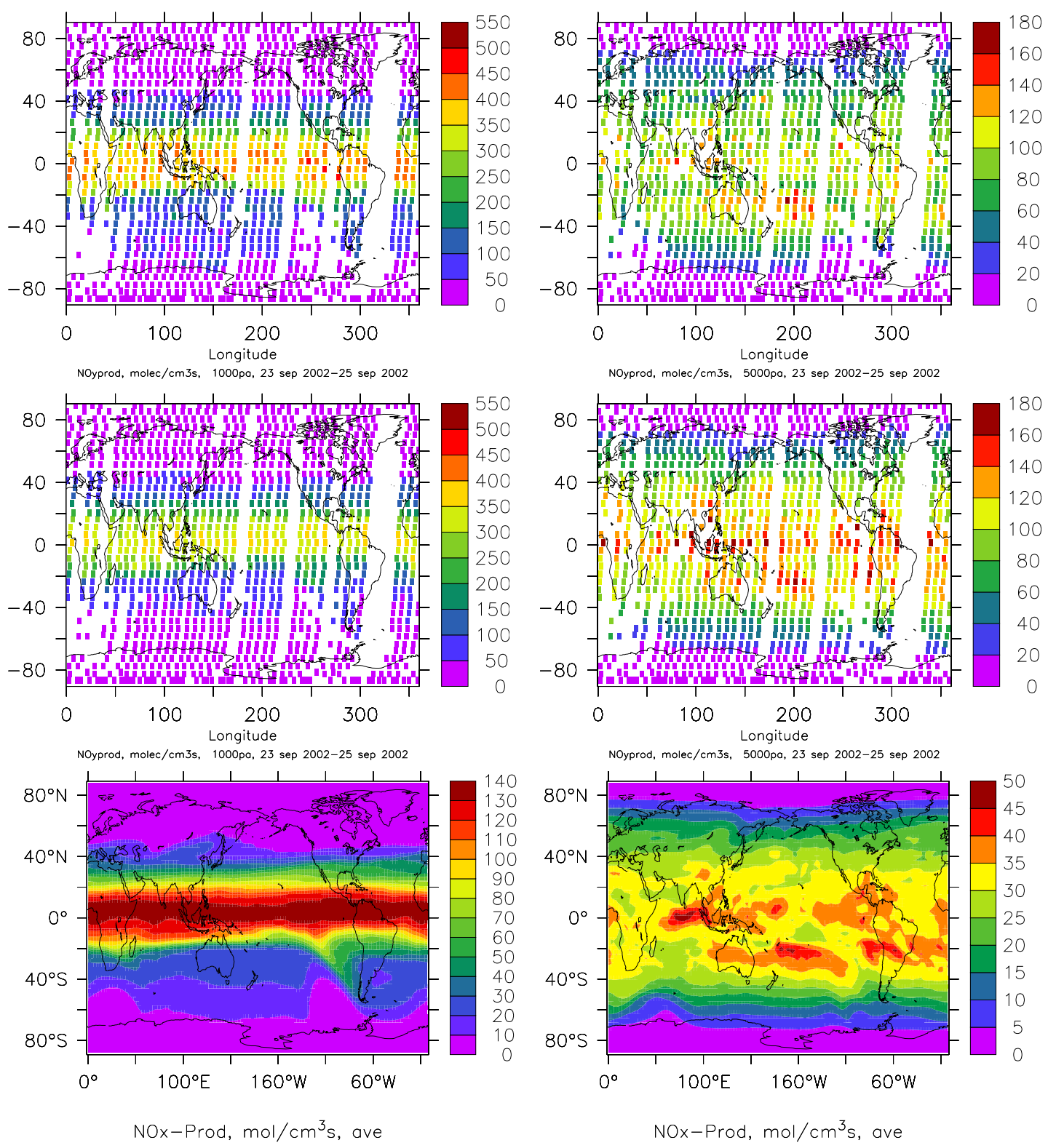

Fig. 10. Upper panels: $\mathrm{NO}_{\mathrm{y}}$-production at $10 \mathrm{~h}$ local time (about 3 times the diurnal average) and $22 \mathrm{~h}$ local time (only polar day near the south-pole) based on MIPAS $\mathrm{N}_{2} \mathrm{O}, \mathrm{O}_{3}, \mathrm{~T}$ and the $\mathrm{O}\left({ }^{1} \mathrm{D}\right) / \mathrm{O}_{3}$ ratio from the model at the data points. $10 \mathrm{hPa}$ left, $50 \mathrm{hPa}$ right. Middle panels: $\mathrm{NO}_{y}$-production at the satellite points using model data only. Lower panels: Diurnal average from the simulation only for the same period (23-25 September 2002).

Acknowledgements. Parts of this study were supported by the European Union Integrated Project SCOUT-O3.

Edited by: M. Dameris

\section{References}

Brühl, C. and Crutzen, P. J.: $\mathrm{NO}_{\mathrm{x}}$-catalyzed ozone destruction and $\mathrm{NO}_{\mathrm{x}}$ activation at midlatitudes to high latitudes as a main cause of the spring to fall ozone decline in the Northern Hemisphere, J. Geophys. Res., 105, 12 163-12 168, 2000.

Butkovskaya, N. I., Kukui, A., Pouvesle, N., and Le Bras, G.: Formation of nitric acid in the gas-phase $\mathrm{HO}_{2}+\mathrm{NO}$ reaction: Effects of temperature and water vapor, J. Phys. Chem. A, 109, 65096520, 2005. 
Crutzen, P. J. and Schmailzl, U.: Chemical budgets of the stratosphere, Planet. Space Sci., 31, 1009-1032, 1983.

Eyring, V., Butchart, N., Waugh, D. W., Akiyoshi, H., Austin, J., Bekki, S., Bodeker, G. E., Boville, B. A., Brühl, C., Dameris, M., Deushi, M., Fioletov, V. E., Frith, S. M., Garcia, R. R., Gettelman, A., Giorgetta, M. A., Grewe, V., Jourdain, L., Kinnison, D. E., Mancini, E., Manzini, E., Marchand, M., Marsh, D. R., Nagashima, T., Newman, P. A., Nielsen, J. E., Pawson, S., Pitari, G., Plummer, D. A., Rozanov, E., Schraner, M., Shepherd, T. G., Shibata, K., Stolarski, R. S., Struthers, H., Tian, W., and Yoshiki, M.: Assessment of temperature, trace species, and ozone in chemistry-climate model simulations of the recent past, J. Geophys. Res., 111, D22308, doi:10.1029/2006JD007327, 2006.

Funke, B., López-Puertas, M., von Clarmann, T., Stiller, G. P., Fischer, H., Glatthor, N., Grabowski, U., Höpfner, M., Kellmann, S., Kiefer, M., Linden, A., Mengistu Tsidu, G., Milz, M., Steck, T., and Wang, D. Y.: Retrieval of stratospheric $\mathrm{NO}_{\mathrm{x}}$ from 5.3 and $6.2 \mu \mathrm{m}$ nonlocal thermodynamic equilibrium emissions measured by Michelson Interferometer for Passive Atmospheric Sounding (MIPAS) on Envisat, J. Geophys. Res., 110, D09302, doi:10.1029/2004JD005225, 2005.

Giorgetta, M. A., Manzini, E., Roeckner, E., Esch, M., and Bengtsson, L.: Climatology and forcing of the quasi-biennial oscillation in the MAECHAM5 model, J. Climate, 19, 3882-3901, 2006.

Glatthor, N., von Clarmann, T., Fischer, H., Funke, B., Grabowski, U., Höpfner, M., Kellmann, S., Kiefer, M., Linden, A., Milz, M., Steck, T., Stiller, G. P., Mengistu Tsidu, G., and Wang, D. Y.: Mixing processes during the Antarctic vortex split in September/ October 2002 as inferred from source gas and ozone distributions from ENVISAT-MIPAS, J. Atmos. Sci., 62, 787-800, 2005.

Glatthor, N., von Clarmann, T., Fischer, H., Funke, B., Gil-López, S., Grabowski, U., Höpfner, M., Kellmann, S., Linden, A., López-Puertas, M., Mengistu Tsidu, G., Milz, M., Steck, T., Stiller, G. P., and Wang, D. Y.: Retrieval of stratospheric ozone profiles from MIPAS/ENVISAT limb emission spectra: a sensitivity study, Atmos. Chem. Phys., 6, 2767-2781, 2006, http://www.atmos-chem-phys.net/6/2767/2006/.

Höpfner, M., von Clarmann, T., Fischer, H., Glatthor, N., Grabowski, U., Kellmann, S., Kiefer, M., Linden, A., Mengistu Tsidu, G., Milz, M., Steck, T., Stiller, G. P., Wang, D.-Y., and Funke, B.: First spaceborne observations of Antarctic stratospheric $\mathrm{ClONO}_{2}$ recovery: Austral spring 2002, J. Geophys. Res., 109, D11308, doi:10.1029/2004JD004609, 2004.

Höpfner M., von Clarmann, T., Fischer, H., Funke, B., Glatthor, N., Grabowski, U., Kellmann, S., Kiefer, M., Linden, A., Milz, M., Steck, T., Stiller, G. P., Bernath, P., Blom, C. E., Blumenstock, Th., Boone, C., Chance, K., Coffey, M. T., Friedl-Vallon, F., Griffith, D., Hannigan, J. W., Hase, F., Jones, N., Jucks, K. W., Keim, C., Kleinert, A., Kouker, W., Liu, G. Y., Mahieu, E., Mellqvist, J., Mikuteit, S., Notholt, J., Oelhaf, H., Piesch, C., Reddmann, T., Ruhnke, R., Schneider, M., Strandberg, A., Toon, G., Walker, K. A., Warneke, T., Wetzel, G., Wood, S., and Zander, R.: Validation of MIPAS $\mathrm{ClONO}_{2}$ measurements, Atmos. Chem. Phys. 7, 257-281, 2007.

Jöckel, P., Sander, R., Kerkweg, A., Tost, H., and Lelieveld, J.: Technical Note: The Modular Earth Submodel System (MESSy) - a new approach towards Earth System Modeling, Atmos. Chem. Phys., 5, 433-444, 2005,

http://www.atmos-chem-phys.net/5/433/2005/.
Jöckel, P., Tost, H., Pozzer, A., Brühl, C., Buchholz, J., Ganzeveld, L., Hoor, P., Kerkweg, A., Lawrence, M. G., Sander, R., Steil, B., Stiller, G., Tanarhte, M., Taraborrelli, D., van Aardenne, J., and Lelieveld, J.: The atmospheric chemistry general circulation model ECHAM5/MESSy1: consistent simulation of ozone from the surface to the mesosphere, Atmos. Chem. Phys., 6, 50675104, 2006,

http://www.atmos-chem-phys.net/6/5067/2006/.

Mengistu Tsidu, G., Stiller, G. P., von Clarmann, T., Funke, B., Höpfner, M., Fischer, H., Glatthor, N., Grabowski, U., Kellmann, S., Kiefer, M., Linden, A., López-Puertas, M., Milz, M., Steck, T., and Wang, D. Y.: $\mathrm{NO}_{\mathrm{y}}$ from Michelson Interferometer for Passive Atmospheric Sounding on Environmental Satellite during the Southern Hemisphere polar vortex split in September/October 2002, J. Geophys. Res., 110, D11301, doi:10.1029/2004JD005322, 2005.

Mengistu Tsidu, G., von Clarmann, T., Stiller, G. P., Höpfner, M., Fischer, H., Glatthor, N., Grabowski, U., Kellmann, S., Kiefer, M., Linden, A., Milz, M., Steck, T., Wang, D.-Y., and Funke, B.: Stratospheric $\mathrm{N}_{2} \mathrm{O}_{5}$ in the austral spring 2002 as retrieved from limb emission spectra recorded by the Michelson Interferometer for Passive Atmospheric Sounding (MIPAS), J. Geophys. Res., 109, D18301, doi:10.1029/2004JD004856, 2004.

Newman, P. A. and Nash, E. R.: The unusual southern hemisphere stratosphere winter, J. Atmos. Sci., 62, 614-628, 2005.

Sander, R., Kerkweg, A., Jöckel, P., and Lelieveld, J.: Technical Note: The new comprehensive atmospheric chemistry module MECCA, Atmos. Chem. Phys., 5, 445-450, 2005, http://www.atmos-chem-phys.net/5/445/2005/.

Sander, S. P., Finlayson-Pitts, B. J., Friedl, R. R., Golden, D. M., Huie, R. E., Kolb, C. E., Kurylo, M. J., Molina, M. J., Moortgat, G. K., Orkin, V. L., and Ravishankara, A. R.: Chemical Kinetics and Photochemical Data for Use in Atmospheric Studies, Evaluation Number 14, JPL Publication 02-25, Jet Propulsion Laboratory, Pasadena, 2002.

Sander, S. P., Friedl, R. R., Golden, D. M., Kurylo, M. J., Moortgat, G. K., Keller-Rudek, H., Wine, P. H., Ravishankara, A. R., Kolb, C. E., Molina, M. J., Finlayson-Pitts, B. J., Huie, R. E., and Orkin, V. L.: Chemical Kinetics and Photochemical Data for Use in Atmospheric Studies, Evaluation Number 15, JPL Publication 06-2, Jet Propulsion Laboratory, Pasadena, 2006.

Solomon, S.: Stratospheric ozone depletion: A review of concepts and history, Rev. Geophys., 37(3), 275-316, 1999.

Spang, R., Remedios, J. J., and Barkley, M. P.: Colour indices for the detection and differentiation of cloud types in infra-red limb emission spectra, Adv. Space Res., 33, 1041-1047, 2004.

Sparling, L. C.: Statistical perspectives on stratospheric transport, Rev. Geophys., 38, 417-436, 2000.

Stiller, G. P., von Clarmann, T., Brühl, Ch., Fischer, H., Funke, B., Glatthor, N., Grabowski, U., Höpfner, M., Jöckel, P., Kellmann, S., Kiefer, M., Linden, A., López-Puertas, M., Mengistu Tsidu, G., Milz, M., Steck, T., and Steil, B.: Global distributions of $\mathrm{HO}_{2} \mathrm{NO}_{2}$ as retrieved from observations of the Michelson Interferometer for Passive Atmospheric Sounding (MIPAS), J. Geophys. Res., 112, D09314, doi:10.1029/2006JD007212, 2007.

von Clarmann, T., Glatthor, N., Grabowski, U., Höpfner, M., Kellmann, S., Kiefer, M., Linden, A., Mengistu Tsidu, G., Milz, M., Steck, T., Stiller, G. P., Wang, D. Y., Fischer, H., Funke, B., GilLópez, S., and López-Puertas, M.: Retrieval of temperature and 
tangent altitude pointing from limb emission spectra recorded from space by the Michelson Interferometer for Passive Atmospheric Sounding (MIPAS), J. Geophys. Res., 108(D23), 4736, doi:10.1029/2003JD003602, 2003.

Wang, D. Y., Höpfner, M., Mengistu Tsidu, G., Stiller, G. P., von Clarmann, T., Fischer, H., Blumenstock, T., Glatthor, N., Grabowski, U., Hase, F., Kellmann, S., Linden, A., Milz, M., Oelhaf, H., Schneider, M., Steck, T., Wetzel, G., López-Puertas, M., Funke, B., Koukouli, M. E., Nakajima, H., Sugita, T., Irie, H., Urban, J., Murtagh, D., Santee, M. L., Toon, G., Gunson, M. R., Irion, F. W., Boone, C. D., Walker, K., and Bernath, P. F.: Validation of nitric acid retrieved by the IMK-IAA processor from MIPAS/ENVISAT measurements, Atmos. Chem. Phys., 7, 721-738, 2007,

http://www.atmos-chem-phys.net/7/721/2007/. 